\title{
Complaint Handling in the Airline Industry: The Way to Enhance Customer Loyalty
}

\author{
Dr. Dina Metwally \\ Faculty of Commerce \& Business Administration, Helwan University. \\ Email: dinametwally2001@gmail.com
}

\section{Doi:10.5901/mjss.2013.v4n10p299}

\begin{abstract}
Organizations with effective customer complaints handling enjoy high level of customers' loyalty. Customers decide to continue with an organization according to its ability to offer what customers need and want. This study aims to understand how customer complaints are managed in the airline industry. A case study of Egyptair is used to achieve the research aim. Data are collected from customers and staff responsible for handling customer complaints. The study reports a number of problems with the process of managing complaints in Egyptair. This causes dissatisfaction of customers and makes it difficult to maintain loyalty. The study introduces a process model for a better handling of complaints in Egyptair. Further, the study suggests a number of implementations at different levels of Egyptair to satisfy customers and enhance customer loyalty.
\end{abstract}

Keywords: customer complaint; loyalty; airline industry; service quality; complaint handling.

\section{Introduction}

Customer complaints are indications of level of satisfaction with product/service quality. Research shows that organizations with effective complaints handling enjoy a high level of customer loyalty. It is argued that unless decision makers understand customer complaints behavior and value the return of complaint handling, they will not be able to recognize the strength of the relationship between complaint handling, loyalty and profits (Goodman, 2006). Customers do not necessarily express their dissatisfaction in the form of complaints, especially when their previous experience implies that the organization does not pay attention to customer complaints. Alternatively, the disappointed customer may choose to move to a competitor or engage in a negative word of mouth communication (Dinnen \& Hassanien, 2011). Research on complaint handling reveals that a small fraction of unsatisfied customers complain. They do so to give the organization the opportunity to correct the problem. There is evidence that some customers do not complain because they are unsure about organizational willingness or ability to resolve disputes fairly. The simplest way for customers is to shift to competitive companies. This encourages the development of an effective and innovative system for handling customer complaints within organizations. The impact of not doing this results in business failure (Dinnen \& Hassanien, 2011). Effective complaint management can save business unwanted costs. For example, negative word-of-mouth publicity from unsatisfied customers means lost revenue and necessitates additional investment in advertising to attract replacement customers.

In today`s highly competitive environment, large companies are highly concerned with obtaining information on customer satisfaction and loyalty (Carvajal et al, 2011). Customer loyalty is a response to company's action as customers decide to continue with an organization according to its ability to offer what customers need and want (Lawfer, 2004). Customer satisfaction has been studied as a factor in its own as well as a determinant of loyalty. Loyalty has been defined as the customer's perception of the extent to which his or her needs, goals and desires have been fulfilled (Oliver, 1999). Meanwhile, Carvajal et al (2011) describes satisfaction as the psychological result of a consumption experience that is not to be confused with its evaluation, but should be seen as the psychological and retrospective judgment of the experience. Accordingly, satisfaction is argued to be the well-being resulting from the consumption experience.

Handling of customer complaints is one of the major determinants of customer satisfaction as well as their decision to stay with an organization. A complaint is defined as an expression of dissatisfaction communicated to an organization with regard to its products (Fornell \& Wernerfelt, 1988). Thus, organizations that do not take customer complaints seriously are likely to lose their customers quickly. Researchers describe desertion as the gradual termination of a relationship due to a number of problems that take place over a long time period (e.g. Hocutt, 1998; Bolton \& Bronkhurst, 1995). Further, it is argued that a severe critical incident may cause an immediate loss of a customer. Nevertheless, slow 
handling of customer complaints is negatively affecting the organizational credibility, image, and reputation. This is a strong reason for losing customers. Fornell \& Johnson (1996) explain that the higher is the level of customer satisfaction with organizational products and/or services, the less is the number of complaints. Further, many researchers argue that satisfaction is a major determinant of loyalty (e.g. Ball et al, 2006; Chiou \& Shen, 2006; Kristensen et al, 2000; Fornell \& Johnson, 1996).

This study aims to understand the process of handling customer complaints in the airline travel. Using a case study of Egyptair, the research explores factors that cause customers' dissatisfaction in handling complaints, investigates causes of problems in the process of managing customer complaints, and suggests a model for an effective handling of complaints in Egyptair.

\section{Service quality and customer satisfaction}

Research about customer satisfaction concludes that it costs more for an organization to gain a new customer than to retain an existing one (e.g. Ranaweera \& Prabhu, 2003; Shin \& Elliott, 2001; Blodgett et al, 1995; Gummesson, 1994). It is argued that customer satisfaction is significant to accomplish profit (Shin \& Elliott, 2001). Customer satisfaction is an important exit and entry barrier, helping the firm to retain its customers and protects the firm against competitors (Fornell, 1992). Accordingly, customer satisfaction has become a major objective of service organizations.

Meanwhile, in most organizations, satisfying customers means less complaints and lower costs in handling failures (Spreng et al, 1995; Clemes et al, 2008). Researchers argue that satisfied customers are willing to pay more for the benefits they receive, i.e. they are less sensitive to price increase (Shin \& Elliott, 2001; Fornell \& Johnson, 1996). Service quality is argued to be an antecedent of customer satisfaction (Cronin et al, 2000). This implies that delivering a high quality of service is the key to achieve customer satisfaction.

The most common definition of service quality is 'customer's perception of service excellence' (Carvajal et al, 2011, p.13189). This definition implies that quality is determined according to customer's evaluation of the level of service provided. As explained by Carvajal et al (2011), perceived quality is characterized by customer's evaluation of the consumption experience that is based on customer's expectation. The idea behind these definitions is that customers perceive service quality according to the current and past experience with service performance (Bhat, 2005).

However, the relationship between service quality and customer satisfaction has been a controversial issue. There has been a debate in the literature regarding the distinction between the two factors as well as the direction of the relationship (e.g. Clemes et al, 2008; Brady et al, 2002; Cronin et al, 2000; Parasuraman et al, 1994). Parasuraman et al (1994) defined service quality as an attitude or a global judgment related to the superiority of the service and confined satisfaction to relate to a specific transaction. Nevertheless, Cronin \& Taylor (1992) argued that service quality was an antecedent of customer satisfaction. Further, they reported that customer satisfaction had a stronger influence on purchase intention than service quality. Cronin \& Taylor concluded that service organization should give a primary focus to total customer satisfaction programs. Similarly, customer satisfaction has been operationalized as a multidimensional construct (Sureshchandar et al, 2002). Sureshchandar et al (2002) argued that service quality and customer satisfaction have different constructs, at least from the customer's point of view.

Different definitions of service quality were introduced in the literature however; all definitions focus on customers' perspectives. They focus on the idea that customers are important dimensions of quality. However, the dimensions of service quality have been also subject to debate in the literature. For example, Parasuraman et al (1988) introduced five dimensions of service quality including tangibles, reliability, responsiveness, assurance and empathy. Rust \& Oliver (1994) introduced three dimensions of service quality and concluded that the service product (i.e. technical quality), the service delivery (i.e. functional quality), and the service environment are critical dimensions of service quality. According to Berry et al (1994) service quality is a function of ten elements: listening to customers, providing reliable service, paying attention to basic service, understanding service design, surprising customers, recovering from service problems, practicing fair play, encouraging teamwork, listening to employees, and creating servant leaders. Four of these elements involve understanding customers' expectations and perceptions and then meeting or exceeding them. These factors include: listening to customers, surprising customers, recovery from service problems, and practicing fair play (Rhoades \& Waguespack, 2000).

Understanding the nature of service quality and its impact on customer satisfaction is significant in identifying the major problems of handing complaints in the airline industry. Different dimensions of service quality are important to evaluate the quality of complaints' handling system. 


\section{Customer satisfaction in air travel industry}

Air transport plays a vital role in moving people or products from one place to another, whether locally or internationally. Movement of goods, people, or freight from one place to another is significantly important. Any business, regardless of size or activity, should be customer focused (Daetz et al, 1995). It is argued that staying close to the customer as well as meeting customers' expectations is the key to a successful business (Oyewole et al, 2007). Kotler et al (1996) argues that the successful business is proactive in its outlook. It anticipates customers' needs and involves them in the early stages of decision making.

Air travel industry has been classified as a more intangible service industry (Clemes et al, 2008; Kloppenborg \& Gourdin, 1992; Shostack, 1977). Although, the growth of the service sector offers new business opportunities, it provides a source of competitive threat for many service organizations (Ostrowski et al, 1993). This is true for air travel industry. There has been a high concern for the past few years in the sheer number of customers that airline industry has to deal with. Usually, airline industry deals with customers in a 'direct contact mode`. This illustrates the importance of the relationship between the organization and its customers (Oyewole et al, 2007). However, customers are becoming more sophisticated and demanding. This increases the significance of a continuous evaluation to determine factors that satisfy or dissatisfy customers. As argued by Senn (1998), business success is not determined by the producer but by the customer. Accordingly, the airline industry has to be a dynamic one, responding to the ever changing demands of its customers (Gilmore \& Pine, 2002).

Prior to 1978 , airline industry was regulated by governments with respect to where and how airlines could operate (Piercy, 2001). Since 1978, because of the Airline Deregulation Act, the competitive structure of airline industry has changed (Levin, 1987; Bailey et al, 1985). Airline industries have been allowed to set their prices as well as to enter and exit the industry upon fulfilling insurance and safety requirements. As a result of this deregulation of airline industry, competition has become more intense. Further, customer satisfaction has become a major requirement to develop a competitive advantage that allows survival with the strong rivalry (Dennett et al, 2000).

Since 1990s, airline companies have been highly concerned with delivering a high level of service quality. Most airline companies started to offer different types of incentives to their customers such as the frequent flyer programs and using a computerized reservation system to build and enhance customer's loyalty (Lee \& Cunningham, 1996; Miller, 1993). However, what seems to make a real difference to customers of airline companies is the quality of service. As Ostrowski et al (1993) argue, when all airline companies have comparable fares and matching frequent flyer programs, the company with the better perceived service is the one that is likely to attract passengers - Figure 1.

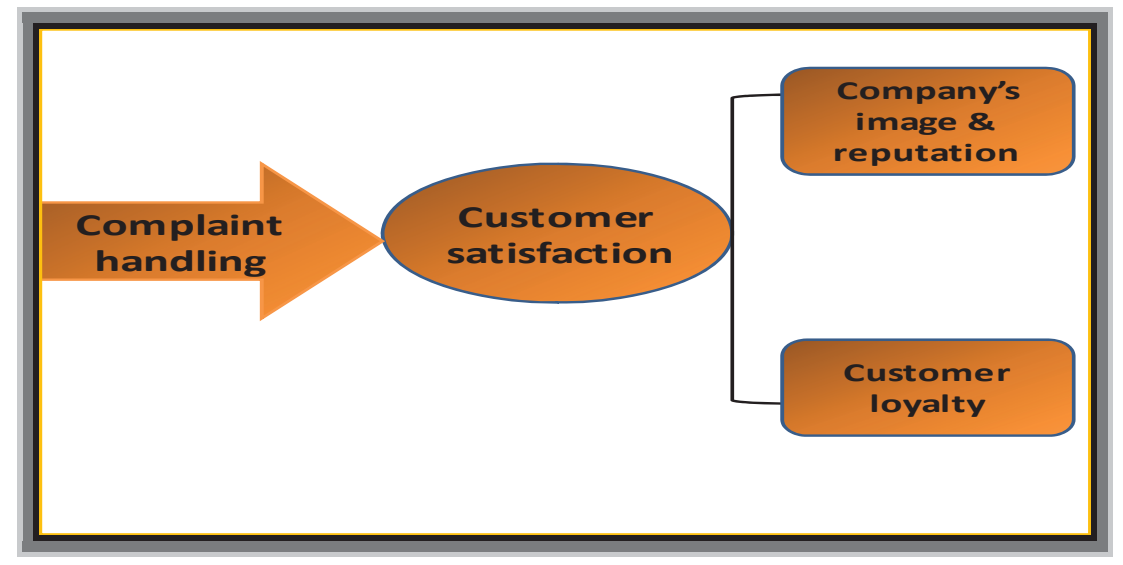

Figure 1. Importance of Effective Complaint Handling

As shown in Figure 1, the system used to handle customer complaints is a major determinant of customer satisfaction that affects company's reputation and image (usually through word-of-mouth communication). This draws attention to the extent to which Egyptair is successful in attracting new customers as well as retaining current ones through using effective complaints handling mechanism. 


\section{Egyptair: Background}

Egyptair was founded in 1932 as Misr Airwork (Davies, 1964). It is a state-owned company with a special legislation permitting the management to operate as if the company was privately owned without interference from the government. The company is self-financing without financial backing by the Egyptian government. The company's network extends throughout Europe, the Middle East, the Far East, Africa, Australia, India, and North America.

In 2002, Egyptair experienced a major corporate re-engineering as its structure was changed from a governmental organization into a holding company with subsidiaries. The move coincided with establishment of the Egyptian Minister of Civil Aviation and the government's ambitious strategy to modernize and upgrade its airports and airline. The airline was given the right to operate without interference from the government and the duty to do so without any financial backing by the Egyptian government.

In 2007, Egyptair was accepted as a member of 'Star Alliance'. By then, Egyptair had already forged commercial and cooperative agreements with several members of the Star Alliance including Lufthansa, Singapore Airlines, Austrian Airlines, Thai Airways International, Swiss International Airlines, South African Airways, Turkish Airlines and bmi.

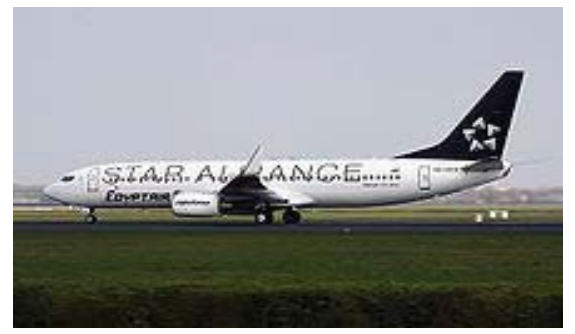

During 2009-2010, the airline announced a new venture with US Aviation Capital Group (ACG) and other Egyptian private and public shareholders to establish a leasing joint venture focusing on the Middle East and Northern Africa region. The new joint venture - named Civil Aviation Finance and Operating Leases (CIAF-Leasing) focuses on a narrow body aircraft.

Being a member of the 'Star Alliance' puts more pressure on Egyptair to meet international standards. An important standard of Airlines worldwide is the mechanism of handling customer complaints and the ability of the company to satisfy customers as well as maintain customer loyalty. Thus, it is significant to study the process of handling complaints in Egyptair. The aim is to identify possible problems in handling complaints and identify methods of improving complaints handling mechanism. This is significant to meet the international standards.

\section{Research objectives}

The aim of this study is enhance customer loyalty through improving the mechanism of complaint handling in Egyptair. Achieving this aim requires achieving the following objectives:

1. To understand the process of complaint handling in Egyptair.

2. To explore customer satisfaction with handling their complaints in Egyptair.

3. To demonstrate the main problems of the system of handling Egyptair customer complaint.

4. To identify possible methods of enhancing the process of complaint handling in Egyptair.

\section{Research methodology}

This study aims to explore issues related to the effectiveness of handling customer complaints in the airline industry. A single case study of Egyptair is used to achieve the research aim and objectives. A single case study research is useful in supporting the exploratory nature of the study. Further, it provides in-depth analysis and understanding of the issues studied including customers' evaluation of complaints handling, staff commitment to complaints' handling, and the mechanism of receiving and handling complaints in Egyptair. This in-depth understanding is essential to provide guidelines for a better mechanism of handling customer complaints.

Data were collected using four main sources: documents, questionnaires, and interviews. 
Data collection was conducted at two stages. Stage one, was concerned with collecting data from customers (passengers). The aim was to investigate customer satisfaction with complaints handling. A randomly selected sample of customers (passengers) was asked a number of closed questions using questionnaires. Questions were related to the process of handling complaints and the extent to which it was meeting customers' expectations. Questions were asked by the researcher and two assistants. Customers were randomly selected at the check in desk, as well as Egyptair office at Cairo airport. Customers were asked about the following:

- The methods of reporting a complaint.

- The attitude of customer complaints staff (e.g. interaction with the customer, attention given to the complaint).

- The speed of responding to a reported complaint (ensuring that the complaint has been received).

- The speed of handling a complaint.

- The steps/process of receiving a complaint (e.g. type of information customers are asked for).

- The steps/process of handling the complaint.

The second stage of data collection was concerned with the staff responsible for dealing with customer complaints. This included both managerial and non-managerial staff. The aim of the second stage of data collection was to clarify certain points that were reported by customers as well as to gain further exploration and understanding of the process of handling complaints in Egyptair. Semi-structured interviews were conducted with three managers and 10 employees. The interview focused on the following:

- Key points in handling customer complaints.

- The process of handling customer complaints in Egyptair.

- Staff satisfaction/evaluation of handling complaints in their company.

- The role of the interviewee (staff member) in handling complaints.

- Factors that influence customer satisfaction with regard to handling complaints.

- Measurement of customer satisfaction with handling their complaints.

- Selection of complaint handling staff.

- Training of complaint handling staff.

- Perception of the importance of handling complaints (i.e. to what extent is handling complaints important at different levels/departments of the organization?)

- Top management perception of customer complaints.

- Management commitment to achieving a satisfactory handling of customer complaints.

- Responsibility of handling customer complaints (i.e. who is responsible for handling customer complaints?).

Selection of the sample in the first and second stages of data collection was influenced by the nature of a case study research that uses an 'analytical' rather than a 'statistical' sample. The idea in a case study research is to choose respondents that best suit the nature of the research (Denscombe, 2000). Also, the size of the sample is highly influenced by the quality of data gathered (Saunders et al, 2007). The researcher should stop including further respondents when data collection reaches a stage at which data gathered from respondents is repetitive and nothing new is added (Yin, 2003).

\section{Research findings}

Studying the process of handling complaints in Egyptair shows that managing complaints is unsatisfactory to customers. All customers included in the study reported their dissatisfaction with one or more issue related to handling their complaints in Egyptair. Issues expressed by customers were further explored and deeply studied with managers and non-management staff. The aim was to compare customers' views to staff views and to identify the main factors behind customers' dissatisfaction. Interviews with Egyptair staff and customers reported a number of issues that are highly responsible for the ineffective mechanism of handling customer complaints. These issues are related to the way Egyptair views complaints and their impact on organization survival. These are explained below:

\subsection{A lack of top management commitment to effective handling of customer complaints}

Management attitudes are reflected in the conduct of employees and the performance of the company. An important finding of this study is related to the way top management perceives customer complaints. This influence the way complaints are handled in Egyptair. Unfortunately, top management perceives complaints as a subjective criticism of the 
effort done by the company. This is reflected in the absence of an organizational philosophy that values customer complaints and an organizational strategy with clear procedures and rules of complaints handling. This was justified by the nature of the Egyptian personality that - as argued by top management- enjoys complaining and criticizing even if there is no real reason for the complaint. Thus, complaints are not seriously handled when they are related to Egyptian passengers (customers). However, complaints by non-Egyptians are differently perceived. Top management perceives complaints by non-Egyptians (especially American and European passengers) as serious ones. It is argued that these customers rarely criticize something, unless there is a strong reason for the criticism. Accordingly, top managers regard complaints from non-Egyptians as objective and have to be dealt with.

Nevertheless, complaints by valuable Egyptian customers are important. Valuable Egyptian customers are defined by top management as 'business and first class passengers who are considered as a major source of income to Egyptair'. However, top management tends to be reactive rather than proactive in handling complaints. Customer complaints are not used as a tool for getting customers' feedback nor improving operations. Also, once a complaint is handled, management and different members of the organization forget about it, i.e. they act as it has never occurred. Specifically, complaints are not considered by top management as a tool for improving service quality.

\subsection{A reactive approach to complaints handling}

Top management perception of customer complaints is reflected in the overall organizational philosophy of handling complaints. Across different levels of the company, complaints are handled using a reactive rather than a proactive strategy. A reactive strategy of complaints handling is reflected in number of issues. First, the main concern is to offer an immediate solution that seems to satisfy the complaining customer. Second, an analysis of the major causes and subcauses of the problem is not a concern for management. Third, customer complaints are not considered an indication of service quality, rather they are perceived as subjective criticism. Fourth, feedback from customer complaints is not used to deal with the main causes of the problem and hence improve the quality of service. Fifth, there is a lack of a customer complaints database that can be used both for handling complaints as well as future improvement of the service.

It is arguable that handling complaints in Egyptair is not a strategic tool to improve the quality of service, improve customer satisfaction, and build and maintain customer loyalty.

\subsection{Poor communication network reflected in a slow handling of complaints}

Studying handling customer complaints in Egyptair reports a significant problem in communication that influences the effective handling of complaints. Communication presents a problem at different dimensions including communication between top management and lower levels of the organization, communication among different departments, and communication between the organization and its customers.

Communication from top management to different levels of the organization, and vise versa, is an issue that highly influences handling complaints. As discussed earlier, top management does not perceive complaints as a crucial issue. Complaints discussed with top management levels are not seriously dealt with unless they are related to a valuable or a non-Egyptian customer. This conveys a message to different organizational levels that customer complaints are not always a 'priority'.

In addition, there is a lack of integration among different departments of the company. It is possible to argue that each department operates in isolation from other departments. Each department focuses on its own work regardless of the impact of other departments as well as its impact on other departments. There is a lack of the ability to view the organization as a whole and to relate different parts of the organization together. This is a strategic issue that does not only affect complaint handling however, it affects the quality of the overall company operations and hence service quality. Specifically, the lack of integration among different departments negatively influences service quality, customers` satisfaction and loyalty.

Communication from the organization to customers, and vise versa, is another issue that negatively influences handling complaints. A common way of addressing a complaint by a customer is through personal relationships, i.e. to report the complaint to one of Egyptair staff that the customer knows personally. This implies that other customers will not be able to express their complaints. Further, it reflects unfair, biased and subjective way of dealing with customers, i.e. customers are not equally treated and not enjoying the same rights. Other methods of receiving complaints include telephone calls (only one line, with no answer most of the time), the complaint template onboard, a letter or an e-mail to the department of customer service. The issue here is that using any of these methods to report a complaint does not 
guarantee an organizational response. The formal way of reporting a complaint is not dealt with seriously nor is it given a serious attention by the customer service. 23 customers out of 25 reported that their complaints have been never dealt with by the organization. 20 customers reported that they have not received any reply from the customer service department.

Thus, there is a serious problem in work integration among different departments as well as among the organization on the one hand and customers on the other. While each department is isolated from others, the organization itself is isolated from its customers.

\section{A Process model for complaint handling in Egyptair}

A major problem in Egyptair is the absence of a specific, clear path of complaints handling that is well-known, understood, and applied by different members of the company. A suggested process that facilitates an effective management of customer complaints involves the following steps (Better Practice Guide 1, April 2009):

1. Receive complaints.

2. Acknowledge complaints.

3. Assess complaints.

4. Investigate the complaint.

5. Respond to the complaint.

6. Follow-up.

7. Consider for system improvement.

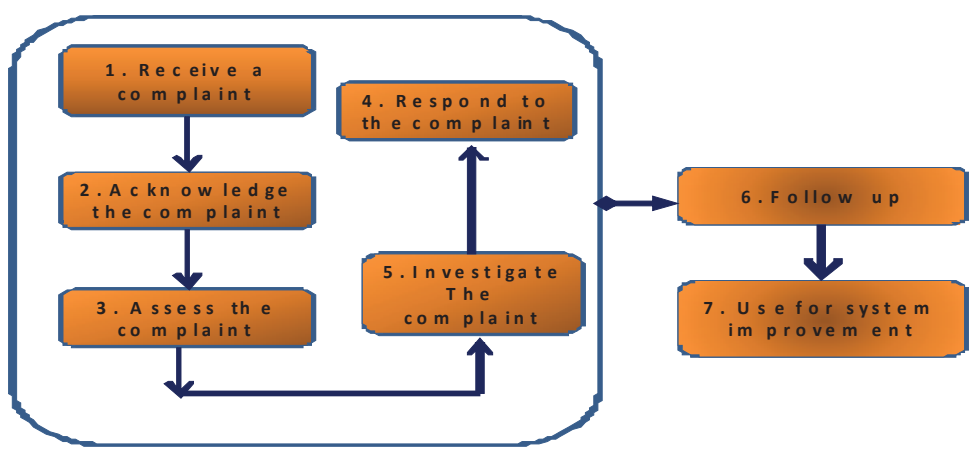

Figure 2. The Process of Handling Complaints

Adopted from: Better Practice Guide 1 (2009), Better Practice Guide to Complaint Handling, April, (Australia: Commonwealth Ombudsman).

\subsection{Receiving complaints}

The first step for effective handling of customer complaints is to have specialized staff and methods of receiving complaints. It is important for customers to know exactly how and where to express/submit their complaints. E-mail, telephone, or face-to-face communications are alternate methods of receiving complaints. Mail complaints through letters is not recommending in the case of Egyptair considering the long delivery time as well as the risk of losing the letter during delivery. What really matters is to make customers aware of these methods so that they can express their complaints easily.

\subsection{Acknowledging complaints}

What is more important than expressing the complaint, is handling it. When customers express their complaints and do not recognize an actual handling of it, they lose confidence in the company. This results in unsatisfied customers who usually shift to a competitive company. Quick acknowledgment of complaints is significant to raise customers ' confidence in the handling of their complaints as well as meeting customers` expectations. Acknowledgement should outline the 
complaint process and provide customer's contact details. Also, it should illustrate the expected time needed to solve the problem, i.e. handle the complaint.

Sometimes, it is useful to use a written acknowledgement to avoid any misunderstanding from both sides (the customer and the company). This is crucial with electronic complaints. The electronic system can be programed to send an automatic response to reassure the customer that the complaint was received and on processing. The automatic response should give the customer an email address as well as a complaint identification (ID) number to use in future contact. If the complaint is made by telephone and cannot be resolved immediately, it is important to explain to the customer how the complaint will be handled and to reassure by sending an email.

\subsection{Assessing complaints}

Early assessment of complaint is important for effective complaint handling. An initial assessment is significant and it is the responsibility of an intake screening unit. A further preliminary assessment by specialist staff is also useful, especially if the complaint is complex or difficult. As the nature of complaints differ widely, deciding whether priority should be given to dealing with one or more aspects of the complaint is necessary.

Assessment is important to clarify the nature of the problem as well as to clarify disputed factual or legal issues. Some complaints can be resolved by means of an explanation or an apology; others seek consideration of a decision, a policy, or a financial compensation. Based on assessment, priority should be given to one or more aspects of the complaint. For an airline company, as Egyptair, it is useful when handling complaints to ask customers (complainants) about their expectations, i.e. the outcomes they are seeking. In some cases, customers' expectations are straight forward such as, an apology, a refund of money paid, or compensation. In other cases, customers do not have selfinterest and complain to improve the welfare of the company. For example, they may desire to raise awareness of the problem or to ensure that other customers will not face the same problem.

\subsection{Investigation}

Acknowledging complaints is meaningless unless an effective investigation is done. Investigation aims to reach a fair, independent view of the issues raised by a complaint and provide an appropriate remedy of the complaint. It is important at this stage to consider three important principles: impartiality, confidentiality, and transparency.

Impartiality is significant to achieve fairness. It is vital to the credibility and success of complaint handling. Impartiality reflects two important issues. First, complaint handling staff should not be defensive about their company. Second, complainants should not be obliged to prove they are right or the company is wrong. A complaint should be handled with an open mind and objectively, regardless of the previous experience between the company and the complainant.

It is significant when handling a complaint to objectively evaluate the facts or evidence provided by the complainant. Special attention and additional investigation should be given to customers who have previously complained on different issues. Also, a complaint about a staff member should be investigated by a different person in the agency to avoid any type of personal bias. It is significant to guarantee that a customer will not face any type of negative treatment because of his/her complaint. This should be an important part of Egyptair policy.

Regarding confidentiality, customers' privacy has to be respected and their complaints have to be investigated in private. A complaint should be investigated in private, and care should be taken when disclosing to others any identifying details of a complaint.

In addition, transparency implies that a complainant is entitled to know how a complaint will be handled and the outcome of the investigation. The complainant should be told about the steps in the complaint process and be given an opportunity to comment on adverse information or before a complaint is dismissed.

\subsection{Response}

Keeping the complainant updated with the outcomes of the investigation is highly influential in raising customers satisfaction and building an effective system of handling complaints. The more complex is the complaint, the better it is to respond in writing. An oral explanation is usually used if this is the method of communication preferred by the complainant or adopted in previous dealings. 
The response should include a detailed explanation of all issues of the complaint. This aims to ensure the complainant that his/her complaint has been handled properly and to build trust between the customers and the company. Privacy should not be a barrier to transparency and accountability. Providing a remedy to the complaint should be taken into consideration. Potential remedies include a better or fuller explanation, an apology, changing decision, expediting action, and providing financial compensation.

\subsection{Follow up}

Complaint handling does not end by responding to the complaint; rather it continues to offer complainants the opportunity to seek review of how their complaints were handled. Follow-up is influential in building employees' loyalty. One way to follow-up with customers is through a telephone discussion between the complainant and a supervisor of the person who handled the complaint. Giving priorities to complaints is useful in the process of follow-up. The more serious, critical, and complex is the complaint, the more significant is to follow-up. However, follow-up with complainants of routine, repetitive, or traditional problems is important as it conveys a message that the company cares for all customers with the same level. This is significant for building customers' loyalty.

\subsection{Use complaints for system improvement}

Complaints might point to a systematic problem in the company. What makes a real difference between an effective and ineffective complaints ' handling system is whether these complaints are used to improve the system or not. An effective process of handling complaints does not end by resolving a customer's complaint, rather it extends to using information gathered through the complaint to improve systematic issues.

A complaint might expose a need to improve the agency`s recordkeeping or a need for a better staff training and support. Also, a delay in resolving a complaint may suggest a problem with efficiency, integration among different departments, or integration between the company and other agencies that are jointly responsible for the subject of the complaint. A review of the company`s policies and procedures can be an important outcome of the complaint handling.

\section{The way to a more effective complaint handling in Egyptair}

Analysis of customer complaint handling in Egyptair reports that serious actions must be taken by the company to improve the mechanism of handling complaints. This is needed to convey a message to current customers that Egyptair has a culture that highly values customers and cares for their satisfaction. The impact of this message is to retain current customers and attract new one as well as enhance customer loyalty. handling.

The following are important actions that Egyptair is recommended to take to improve the system of complaint

\subsection{Centralized handling of complaints}

Establishing a department for the management of customer complaints is essential as a first step to improve the quality of service in Egyptair. This is important for raising customer satisfaction as well as maintaining customer loyalty. All complaints should be handled centrally through this department. This department is responsible for contacting other departments to take necessary actions to solve the problem. Follow up is also the responsibility of the complaint management department.

\subsection{Build management commitment to complaint handling}

Management attitudes are reflected in the conduct of employees and the performance of the company. Building management commitment starts from top management and extends to different levels of the organization. This might be achieved through implementing the following:

- The head of Egyptair (CEO) should be responsible for making complaint handling a priority for the company. One way to do this is to consider the standards of complaint handling as a major part of Egyptair business plan and service standards. Also, it can be achieved by receiving regular internal reports on the quality and timelines of complaint handling as well as using complaint information in improvement of service delivery. 
- Supporting managers responsible for complaint handling to better to do their jobs. This could be done through recruiting suitable personnel and provide comprehensive training to complaint handling staff. Also, it is important to promote a strong internal network to enable complaint handling staff to work and be supported with others and to provide regular reports to other areas of the agency on issues arising from complaint handling

- Top-level commitment to effective complaint handling establishes the motive and incentive for all personnel to strive for consumer satisfaction. Management's role begins with the preparation of written policies and procedures for complaints handling. These policies and procedures must ensure fair and speedy complaint resolution. Effective and clear communication of these policies and procedures to all departments of the organizations must be ensured.

- Management role must extend to the regular review of complaint management policies and procedures. This review is necessary to improve complaint handling system, pay special attention to refining communication and coordination between complaint management and other departments.

\subsection{Periodic customer survey}

An organization that seeks customers satisfaction should not wait for customers to report a complaint, rather asking customers periodically about their satisfaction with service level is argued to be the key to maintain loyalty.

Periodic surveys will reveal whether customers feel they have been well served by the complaint-processing procedures. Also, they explore customers`assessment of different policies and procedures as well as their satisfaction with employees' communication skills and face-to-face interaction. Feedback of customers' surveys is significant for improving level of service quality, enhancing customers` satisfaction, and maintaining loyalty.

\subsection{Training \& development of complaint handling staff}

What is needed in Egyptair is not only staff training; rather staff development is a necessity. Development is a broader word than training. It aims to building employees' personal skills rather than specific task issues. Training should focus on improving communication skills and heighten the staff awareness of customers' needs according to different economic classes, educational background, social classes, and cultural background. What is needed for effective complaint handling system in Egyptair is a self-belief of different members of complaint-management department that the survival of this organization is based on customers. This belief should extend to all staff members to reflect the overall philosophy of the organization.

Staff of complaint-management department should be patient, articulate, and able to balance the interests of the company with the customers. Also, Egyptair staff should be able to communicate legitimate customer complaints to concerned management level to initiate and support any necessary modification in organizational policies and procedures.

\subsection{Building a highly integrated system}

Handling customer complaints in a way that satisfies customers and maintains customer loyalty requires an integrated system of different departments of the organization. A complaint handling system must be visible and accessible to facilitate serving customers. Integration and coordination between different departments is a necessity to maintain an effective complaint handling system. This integration will not be achieved without the commitment of top management. Top management commitment and support to complaints' management is transferred to different levels of management and reflected in the development of an organizational philosophy that values complaints and recognizes that its management is the reason behind organizational survival. One way to spread this philosophy within the organization and convey it to customers is through using Egyptair posters and signs that contain a message reflecting the importance of customers and their complaints. These signs should be used in sales and service areas, on tickets and sales slips, in advertising, on tickets' labels and covers, and in email messages.

\subsection{Implementing complaint self audit checklist}

This checklist aims to evaluate different departments and divisions with respect to effective complaint handling. It also 
aims to check compliance evaluation to new policies and standards set by top management. This should be done regularly. It is recommended to do it monthly until the system is well established and understood by different members of the company. This is useful in system improvement through gathering information about factors that cause customers' dissatisfaction. The checklist should be developed based on factors that cause customers satisfaction in general with specific focus given to factors that caused customers' dissatisfaction with Egyptair. Past performance of Egyptair is important in identifying these factors. The checklist might be completed by senior members of the complaint team or by different members of the team.

\section{Research limitations}

This study introduces important results regarding the handling of customer complaint in the airline industry. However, the study was conducted in the Egyptian airline industry [Egyptair]. Thus, generalization of research findings makes it important to conduct the same study in other airline companies. Further, the study took place in Egyptair branch in Cairo. A further investigation of research issues in other branches in other Egyptian governorates (e.g. Alexandria, Port-Saed, Sohag) is important to generalize the findings of this study to Egyptair. Nevertheless, conducting the same study in other Egyptair branches may introduce new system problems and/or weaknesses.

Meanwhile, findings of the study are limited to Egypt. Generalization to other Middle Eastern countries requires conducting the same study in different countries such as Jordon, Lebanon, Iraq. A comparison between research findings in different Arab/Middle Eastern countries is expected to explore issues related to national culture and its impact on customer behavior.

\section{Conclusion}

Complaints offer businesses an opportunity to correct immediate problems. They frequently provide constructive ideas for improving products, adapting marketing practices, upgrading services, or modifying promotional material and product information. Research about customer satisfaction concludes that it costs more for an organization to gain a new customer than to retain an existing one. It is argued that customer satisfaction is significant to accomplish profit. Accordingly, customer satisfaction has become a major objective of service organizations. In most organizations, satisfying customers means less complaints and lower costs in handling failures.

The system used to handle customer complaints is a major determinant of customer satisfaction that affects company's reputation and image. Air transport plays a vital role in moving people or products from one place to another, whether locally or internationally. Since 1990s, airline companies have been highly concerned with delivering a high level of service quality. However, what seems to make a real difference to customers of airline companies is the quality of service.

The aim of this study was to enhance customer loyalty through improving the mechanism of complaint handling in Egyptair. Studying the process of handling complaints in Egyptair showed that managing complaints was unsatisfactory to customers. This was because the way Egyptair viewed complaints and their impact on organization survival

A seven steps process of handling complaints is highly recommended to facilitate and improve the management of customer complaints in Egyptair. For a more effective complaint handling, Egyptair needs to apply a centralized system of handling complaints, build top management commitment, use periodic customer surveys, use complaint self audit checklist, and build an integrated communication system.

\section{References}

Ball, D., Coelho, P. \& Vilares, M. (2006) `Service Personalization and Loyalty`, Journal of Service Marketing, 20(6): 391-403.

Bailey, E.R., Graham, D.R. \& Kaplan, D. (1985) 'Deregulating the Airlines', MIT Press Series on Regulation of Economic Activity, (Cambridge: MIT Press).

Berry, I., Parasuraman, A. \& Zeithaml, V. (1994) 'Improving Service Quality in America: Lessons Learned', The Academy of Management Executive, 8(2):32-52.

Better Practice Guide 1 (2009), Better Practice Guide to Complaint Handling, April, (Australia: Commonwealth Ombudsman).

Bhat, M. (2005) 'Service Quality Perceptions in Banks: A Comparative Analysis`, Journal of Business Perspectives, 9(1): 77-99.

Blodgett, J.G., Hill, D.J. \& Tax, S.S. (1997) 'The Effects of Distributive Justice, Procedural and Interactional Justice on Post-complaint Behavior', Journal of Retailing, 73(2): 185-210.

Bolton, R. \& Bronkhurst, T. (1995) 'The Relationship between Customer Complaints to the Firm and Subsequent Exit Behavior', Advanced Consumer Research, 22: 92-100. 
Brady, M.K., Cronin, J.J. \& Brand, R.R. (2002) 'Performance-only Measurement of Service Quality: A Replication and Extension`, Journal of Business Research, 55(1): 17-31.

Carvajal, S., Ruzzi, A., Nogales, A., et al (2011) 'The Impact of Personalization and Complaint Handling on Customer Loyalty', African Journal of Business Management, 5(34): 13187-13196.

Chiou, J. \& Shen, C. (2006) 'The Effects of Satisfaction, Opportunism, and Asset Specificity on Consumers` Loyalty Intention toward Internet Portal Sites', International Journal of Service Industry Management, 17(1): 7-22.

Clemes, M., Gan, C., Kao, T., et al (2008) 'An Empirical Analysis of Customer Satisfaction in International Air Travel', Innovative Marketing, 4(2): 49-63.

Cronin, J. \& Taylor, S. (1992) 'Measuring Service Quality: A Reexamination and Extension`, Journal of Marketing, 56(3): 55-68.

Cronin, J.J, Brady, M.K. \& Hult, G.T.M. (2000) 'Assessing the Effects of Quality, Value, and Customer Satisfaction on Consumer Behavioral Intentions in Service Environments', Journal of Retailing, 76(2): 193-218.

Daetz, D., Bernard, B. \& Rick, N. (1995) 'Customer Integration’, (USA: John Wiley \& Sons).

Davies, R.E. (1964) `A History of the World's Airlines', (UK: Oxford University Press).

Denscombe, M. (2000) The Good Research Guide for Small-Scale Social Research Projects. (Buckingham: Open University Press).

Dennet, C.E., Ineson, M., Stone, G.J., et al (2000) 'Pre-Bookable Services in the Chartered Airline Industry: Increasing Satisfaction through Differentiation', The Service Industries Journal, April, 20(2): 82-94.

Dinnen, R. \& Hassanien, A. (2011) 'Handling Customer Complaints in the Hospitality Industry', International Journal of Customer Relationship Marketing and Management, 2(1): 69-91.

Egyptair, Origin and Early History. [online] available: http://en.wikipedia.org/wiki/EgyptAir (7 February,2013).

Egyptair Official Website. [online] available: http://www.egyptair.com/English/Pages/ splashpage.aspx (15 February, 2013).

Fornell, C. \& Wernerfelt, B. (1988) 'A Model for Customer Complaint Management', Marketing Science, 7(3): 287-298.

Fornell, C. (1992) 'A National Customer Satisfaction Barometer: The Swedish Experience', Journal of Marketing, January, 56: 6-21.

Fornell, C. \& Johnson, M. (1996) `American Customer Satisfaction Index: Nature, Purpose, and Findings', Journal of Marketing, 60(4): 7-18.

Ganesan, S. (1994) 'Determination of Long-Term Orientation in Buyer-Seller Relationships', Journal of Marketing, 58(4): 1-19.

Gilmore, J.H. \& Pine II, J.B. (2002) 'Impact Is No Longer Enough', contextmag.com/archives/19971.

Goodman, J. (2006) `Customer Loyalty: Manage Complaints to Enhance Loyalty`, Quality Progress, February, pp: 28-34, www.asq.org

Gummesson, E. (1994) 'Making Relationship Marketing Operational', International Journal of Service Industry Management, 5(5): 5-20.

Hocutt, M. (1998) 'Relationship Dissolution Model: Antecedents of Relationship Commitment and the Likelihood of Dissolving a Relationship', International Journal of Service Industry Management, 9(2): 189-200.

Kirstensen, K., Martensen, A. \& Gronholdt, L. (2000) 'Measuring Customer Satisfaction: A Key Dimension of Business Performance', International Journal of Business Performance Management, 2: 157-170.

Kloppenborg, T.J. \& Gourdin, K.N. (1992) 'Up in the Air about Quality`, Quality Progress, February, pp: 31-35.

Kotler, P., Ang, S.H., Leong, S.W., et al (1996) 'Marketing Management: An Asian Perspective`, (Singapore: Prentice Hall).

Lawfer, M. (2004) 'Why Customers Come Back: How to Create Lasting Customer Loyalty', (New Jersey: The Career Press).

Lee, M. \& Cunningham, L.F. (1996) 'Customer Loyalty in the Airline Industry’, Transportation Quarterly, 50(2): 57-72.

Levin, M.E. (1987) 'Airline Competition Deregulated Markets: Theory, Firm Strategy, and Public Policy', The Yale Journal on Regulation, Spring, 4(2): 393-494.

Miller, C. (1993) 'Rewards for the Best Customers: Loyalty Programs Increase as Marketers Try to Build Relationships', Marketing News, July 5, pp: 1-6.

Oliver, R. (1999) 'Whence Consumer Loyalty', Journal of Marketing, 63(special issue): 33-44.

Ostrowski, R.L., O'Brien, T.V. \& Gordon, G.L. (1993) 'Service Quality and Customer Loyalty in the Commercial Airline Industry`, Journal of Travel Research, 32(2): 16-24.

Oyewole, P., Sankaran, M. \& Choudhury, P. (2007) 'Marketing Airline Services in Malysia: A Consumer Satisfaction Orientation Approach', Innovative Marketing, 3(1): 56-70.

Parasuraman, A., Zeithaml, V.A. \& Berry, L.L. (1988) 'SERVQUAL: A Multiple-Item Scale for Measuring Consumer Perceptions of Service Quality', Journal of Retailing, 64(1): 12-40.

Parasuraman, A., Zeithaml, V.A. \& Berry, L.L. (1994) 'Reassessment of Expectations as a Comparison Standards in Measuring Service Quality: Implications for Further Research`, Journal of Marketing, 58(2): 111-124.

Piercy, N. (2001) 'Reinventing the Airline Business: If You Want Dinner, Go to a Restaurant!', Business Cases Organizations, Case No. 0068.

Ranaweera, C. \& Prabhu, J. (2003) 'The Influence of Satisfaction, Trust and Switching Barriers on Customer Retention in a Continuous Purchasing Setting', International Journal of Service Industry Management, 14(4): 374-395.

Reference for Business, History of Egyptair. [online] available: http://www.referenceforbusiness.com/history2/63/EgyptAir.html (16 February, 2013).

Rhoades, D. \& Waguespack, B. (2000) 'Service Quality in The US Airline Industry: Variations in Performance Within Airlines and between Airlines and the Industry', Journal of Air Transportation World Wide, 5(1): 60-77.

Rust, R.T. \& Oliver, R.L (1994) 'Service Quality: Insights and Managerial Implications from the Frontier', in Rust, R.T. \& Oliver, R.L. (eds.) 'Service Quality: New Directions in Theory and Practice', (New York: Sage Publications), pp: 1-19.

Saunders, M., Lewis, P. \& Thornhill, A. (2007) 'Research Methods for Business Students', $4^{\text {th }}$ edn., (London: Prentice Hall). 
Senn, J.A. (1998) `Information Technology in Business-Principles, Practices, and Opportunities`, (New Jersey: Prentice Hall).

Shin, D. \& Elliott, K. (2001) 'Measuring Customer Overall Satisfaction: A Multi-Attributes Assessment Services', Marketing Quarterly, 22(1): 3-19.

Shostack, L.G. (1977) `Breaking Free Product Marketing', Journal of Marketing, April, 41: 73-80.

Spreng, R.A., Harrell, G.D. \& Mackoy, R.D. (1995) 'Service Recovery: Impact on Satisfaction and Intentions', Journal of Service Marketing, 9(1): 15-23.

Surreshchandar, G.S., Rajendran, C. \& Anantharaman, R.N. (2002) 'The Relationship between Service Quality and Customer Satisfaction- A Factor Specific Approach', Journal of Service Marketing, 16(4): 363-379.

Yin, R.K. (2003) 'Case Study Research: Design and Methods', 3rd edn., (Thousand Oaks: Sage Publications). 